DOI https://doi.org/10.32837/app.v0i67.1162

UDC 321.6

\author{
S. S. Teslenko \\ orcid.org/0000-0002-2190-6173 \\ Postgraduate Student at the Department of Politology \\ Taras Shevchenko National University of Kyiv
}

\title{
POLITICAL PRACTICES OF TRANSFORMATION OF EAST AND SOUTHEAST ASIA COUNTRIES
}

Introduction. Current studies of political transitology describe different options for the transition to authoritarianism. Researchers of democratization, for example, warn us about the "third wave of authoritarianism", which is characterized by the authoritarianism of practices that at the time of deployment have become more "objective and dynamic", gradual and rather unconventional (Glasius, 2018 , p. 518). In both authoritarian regimes and democracies, actors pursuing authoritarian intentions creatively use a variety of tools to weaken democracy while maintaining or creating nominally democratic institutions. On the surface, these events may give the impression of an expansion of democracy, but careful empirical research reveals that they serve "typically authoritarian purposes" (Svolik, 2012, p. 13). Meanwhile, some democratically elected leaders are also constantly innovating to reduce the scope for freedom of expression and accountability, but these practices are often subtle and out of sight, making it difficult to identify them with standard democracy rollback rates.

The phenomenon of modernization has long been studied in detail by various socio-humanitarian disciplines. The focus of attention of researchers is different models of modernization, including those that differ significantly from the model that can be conditionally considered classical, describing the way of development that societies and states of Western Europe and North America followed since the New Age and which, in general, continue to adhere to present time. In particular, a separate area of research has become the consideration of modernization models based not on a democratic political tradition, but on authoritarian principles - the so-called authoritarian modernization (Sztompka, 1992, p. 21-23).

The well-known American political scientist D. Bell and a number of other scholars who develop a model of "illiberal" democracy consider the Chinese model of democracy to be quite viable, when power, in accordance with the traditional principles of social structure, is delegated to those who have passed an authoritative national competition (Bell, 2006, p. 153-179).

The main purpose is to analyze the political practices of political transformation of East and Southeast Asia; to describe the factors that influenced the implementation of modernization projects in the countries of the region; to identify specific features of the political transformations of the states of the region associated with the formation of non-Western democracies on the basis of "authoritarianism of development".

Research methods. The study used descriptive, systematic and comparative methods, which allowed to analyze the political practices of political transformation of East and Southeast Asia.

The descriptive method helped to carry out the general research of model of modernization in the specified region, having allocated characteristic features of the given practices.

The systematic method made it possible to analyze political modernization in the context of the non-Western political process.

Using a comparative method, the case studies of the implementation of modernization policy practices in the Asia-Pacific region were studied.

Results. The specificity of the non-Western political process is due to the uniqueness and identity of the Eastern (Asian), Latin American, African societies as parts of the non-Western world.

Non-Western states, which have not recently been seen as competitors of global leaders, seek to take a real part in international competition, indicating the ambitions of regional or global leadership.

Let us turn to the experience of political modernization of the East Asian states. East Asia is a large region located in the east of Eurasia. It includes countries such as China, Japan, Taiwan, North 
and South Korea, Mongolia, as well as the countries of Southeast Asia (Thailand, Indonesia, Malaysia, Vietnam, Cambodia, Burma, Singapore, Philippines and Brunei).

The most important characteristic of a modernizing society is the constant search for forms and mechanisms to ensure its own security. And within the framework of the modern modernization paradigm, reflecting the processes of modern social change, security cannot be understood as the protection of currently existing structures and relations. Ensuring the safety of society, on the contrary, involves active stimulation and modernization of ineffective social institutional formations and interactions (Organski, 1965, p. 40-42).

Colonization had a great influence on the modernization processes in the countries of the East. Colonial synthesis appears as a close intertwining and interaction of the foreign policy activity of the capitalist West, which is the subject of synthesis, and the traditional feudal-tribal East, which has become the object of synthesis. The transformation of the states of the East was reduced, first of all, to the strengthening of the positions of the national state, which in the colonies was revived after decolonization, in dependent countries began to strengthen in the process of reforms and revolutionary transformations. The character of such a state remained authoritarian, but at the same time it was legitimate and looked democratic in the eyes of the population. Modernization has become an integral part of political practice, since it was aimed at ensuring independence and national security.

Carrying out the transformation of political and economic institutions, some countries of the East embarked on this path later than the West, but managed to offer their own path, not equivalent to Westernization, and preserve their cultural and civilizational identity.

The specificity of the socio-cultural matrix of the East was the type of society harmoniously built into nature. The development of Eastern civilizations until the middle of the 19th century took place in a closed ethno-cultural environment, and the processes of modernization were greatly influenced by factors of social development that had developed over millennia, which were different from European civilizations. Among them: collectivism as a functional and production value; the contemplative, passive nature of society; the predominance of collectivism and tribal power in political relations; the absence of the institution of private property as an independent factor of being; the relative stability of cultural archetypes that determine the inertia of culture; the dominance of reconstruction and recovery tactics; rejection of democratic forms of organizing the political process as a central element of the state system; a special type of management culture through a strictly hierarchical bureaucracy; extraordinary controls based on personal, emotionally coloured relationships.

Social capital has become a social support for the formation of the eastern model of modernization, since traditional societies are focused on diverse forms of collective activity, social cohesion within clan and clan structures. Such components of social capital as trust, civic identity, and tolerance perform important functions for the political system of legitimizing power structures, integrating and mobilizing Eastern society in the face of modernization challenges.

Oriental societies are characterized by socio-economic diversity, which is reflected in ethnic and confessional differentiation. All strata of society, despite the way of life and occupation, maintain close contacts and ties with the tribe, clan, community, confession, which cannot but give rise to ideological diversity and the associated polymorphism of the political process.

The main elements of political culture in the East are stereotypes, ideas of mass consciousness about the legitimacy of power, based on centuries-old traditions. Among them are the attitudes of the mass consciousness of the traditional society towards righteous rule; stereotypical image of an ideal leader based on political myths; the stereotype of perception of borrowings based on the principle of "stranger - ours", "we" and "they"; functionality of tribal, clan ties in modern conditions; the stereotypical reaction of individual and mass consciousness to the power of the state and the foundations of such legitimacy. The following postulate remains a political formula: the domination of the state is latent, providing a measure of solidarity.

Another specific feature of political modernization in the states of the East is its authoritarian character. However, political authoritarianism not only builds on traditional political culture, but also transforms it. As a rule, the strengthening of the role of the state in the process of modernization was accompanied by the establishment of authoritarian regimes - "development authoritarianisms" or "modernizing authoritarianisms". Such regimes ensured (both by economic and administrative 
methods) a significant increase in the share of investment in GDP, including at the expense of the wealthy strata of society. They pursued a policy aimed at the technological modernization of the existing industry, and at the creation of fundamentally new economic sectors for the country, provided conditions for the preparation of an appropriate workforce, and created national systems of education and scientific research. At the same time, "development authoritarianisms" used and are using not only repression, implementing "coercion to progress", they also relied on public consensus and solidarity in addressing issues of increasing material well-being and expanding opportunities for vertical social mobility (Glasius, 2018, p. 520-525).

Modernizing authoritarianism contributed to the formation of a power pyramid with a national leader at the head, who personifies the political regime and is the guarantor of the ongoing transformations. This political regime does not erect insurmountable obstacles on the way to democracy, it promotes the growth of the middle class, creates the preconditions for political liberalization and gradually erodes the foundations of its own existence (Lührmann, Lindberg, 2019). The tough nature of government, combined with certain traditions of an uncritical perception of power, gave a stunning economic effect, led to the revitalization of the population and an increase in the legitimacy of the regime in many states of the region.

The democratic model, in which the primary formations of society will be independent in decision-making, develop local self-government and delegate powers, has not become widespread in the East. However, the general trend in the political development of the region is the formation of models of non-Western democracy. The researcher believes that in non-Western democracies there is a different relationship between democracy and constitutional liberalism than in liberal ones, at the same time, they are more democratic (and more competitive) than illiberal or participatory democracies. An analysis of the socio-cultural characteristics of the countries of the non-Western political process and different ways of their transformation in the presence of general patterns allows us to reveal the presence of different types, models of democracies (not only European and American types), including the Eastern type (Japanese, Singaporean, Indian, South Korean, Malaysian, Taiwanese, Israeli, Turkish, etc.) (Morgenbesser, 2020, p. 32).

Comparative studies allow us to talk about the specifics of political modernization in the states of East, Central Asia and the Middle East, which is based on common civilizational principles for these regions of the East (the so-called civilization model) and on national or country models characteristic of one or more states characterized by specific signs.

Some of the eastern countries have managed to prove their worth in carrying out modernization as a national project to meet the challenges of the time and the outside world. First of all, this applies to the countries of East Asia, which have a vivid cultural identity, their own traditions of statehood and a long history.

At present, researchers identify four "echelons of development" or four waves of development in the region. It was headed by Japan with its successful modernization. This was followed by the rapid rise of newly industrialized countries (Hong Kong, Singapore, the Republic of Korea and Taiwan) on the basis of an effective industrial strategy, namely, the creation of an export-oriented model of economic development with the help of foreign capital and technology. Further, a group of Southeast Asian countries (Indonesia, Malaysia, Thailand, Philippines) joined the development process. China, as well as the countries of Indochina, are considered as the fourth wave, which is already accumulating capital investments from all of the above countries.

No matter how great the contrast between "traditional" and "modern" in East Asian societies, successful modernization here was based on elements of traditional regulation that correspond to its direction. The sustainable functioning of the elements of modernity to a large extent depends on the availability of appropriate traditional prerequisites, on their use and inclusion in the modern system of societies in the region. In the process of modernization of the states of the region, a synthesis of the traditional national and modern Western was carried out. This is not only Confucian work ethic and management, but also the highest rates of saving and accumulation in the world, and the closely related growth rates (both "Confucian capitalism" in Japan, Korea and Taiwan, and "Confucian socialism" in China, where traditional values are gradually restoring lost positions, and Confucianism itself is turning from an "insignificant" addition to formational affiliation more and more distinctly into an integral characteristic of the civilizational core). 
It was these non-Western polities that managed to catch up with the West. The success of modernization projects in the South-East states is due to the fact that the innovation component has become a priority for the state and is carried out in a highly competitive environment (for example, this applies to South Korea and Singapore). According to a number of experts, in the XXI century Southeast Asia will gradually become the main trendsetter of political and socio-economic fashion. And now, fierce competitive wars are being waged in this region. And in these conditions, only an innovative leap will allow one to assert itself, and even more so to gain the upper hand over opponents. This was fully demonstrated by Singapore, where the forced modernization made it possible to dramatically raise the country's status and provide it with significant positions in the economic and political spheres. In South Korea, the factor of regional competition is complemented by the problem of political competition. Since 1953, the ROK has been in a state of "cold war" with the DPRK, and in order to mobilize support from the population, its leadership needs to regularly demonstrate achievements and ensure a permanent increase in the living standards of its citizens (Yang, 1994).

The common civilizational "credo" determining the internal political course of socio-economic and political transformations in the states of East Asia was the creation of competitive socio-economic advantages and an increase in the level of well-being for the population, ensuring the survival and progress of the nation. For example, the Malaysian political leader Mahathir saw not the transit of democratic institutions as the primary task of modernization, but a change in the sociocultural values and attitudes of the Malays through the radical re-education of the Malay community in order to preserve national values and behavioural stereotypes that contribute to the ongoing transformations.

The modernization process in East Asia was faster than, for example, in Europe. It can be characterized as "compressed" or "condensed" because it took place in a relatively short period of time and mainly in urbanized centres. The results of such modernization are "compressed" or "complex", which Ernest Blok called "simultaneity (synchronicity) of non-simultaneity". When external challenges and exogenous factors were included in the development process in the East Asian region, it began to occur rather quickly while maintaining self-identification. The fast time frame for the implementation of modernization projects leads to the transformation of institutions and social relations in a new social configuration, squeezes modernity, therefore, "non-system" actors appear both within the state and in the international arena (Martinelli, 2005, p. 44-46). At the same time, the development of all these countries does not aim at a radical change in socio-cultural foundations, as Japan did in its time.

In this regard, it is worth taking into account the importance of the cultural traditions of the peoples of the region for accelerated modernization. In particular, a great role was played by the tradition of seeking harmony in diversity, the desire to reconcile opposites, maintaining continuity in the course of changes - a tradition associated with the teachings of Confucianism, Buddhism and Taoism. There is no doubt that the habit of hard work, a kind of social paternalism, respect for the authority of elders and the state, as well as adherence to community principles, contributed to a successful development policy.

The political features of the East Asian model are in the following trends:

1. The special role of governments in planning modernization strategies based on the theory of economic growth, which provides for a high level of savings and savings and investment.

2. The leading position in the implementation of transformations was assigned to the state bodies conducting the "miracle" - ministries and departments (Japan), agencies (China), planning and development councils (Korea), engaged in careful planning, strategies for growing individual enterprises, strategic areas and national leaders.

3. Competent bureaucracy with minimal corruption.

4. Authoritarian transformation methods. If in the 1990's it was believed that advanced states can be with a liberal political regime, then in the early 2000's such a dogma was called into question. A number of authoritarian and even semi-totalitarian regimes have made technological and scientific breakthroughs, creating real competition for Western democracies. This applies to the People's Republic of China, South Korea, and Singapore (Waldner, Lust, 2018, p. 95). 
The specificity of the political practices of the region lies in the fact that there is the least polarization of government models, which contributes to the formation of a compromise between various political forces regarding the general vector of political and economic modernization of the region. Modernization is not perceived as Westernization, i.e. the inevitability of the movement of state formations towards the Western model of development, but as a special way of development, during which the synthesis of Western political experience (democracy), the norms of constitutional liberalism and autochthonous political culture in all its specific confessional, country, regional originality is carried out. Examples include the Westminster model of government and the caste system in India; Buddhist statehood and democracy in Sri Lanka; the dominant role of the Liberal Democratic Party in Japan (until recently); confessional pluralism with the soft domination of Islam in Indonesia; the presence of a dominant charismatic political leader (minister-mentor) in Singapore; Chineseized Marxism, internal party democracy, direct elections at the grassroots administrative level, emphasis on the rule of law and Confucian ethics in China.

Conclusions. In accordance with the purpose, the study performed the following tasks:

1. The analysis of political practices of political transformation of the countries of East and SouthEast Asia is carried out. The region is specific in terms of a special, non-Western approach to modernization, which has resulted in intensive and effective reforms of a political and economic nature.

2. Describes the factors that influenced the successful implementation of modernization projects in the region. So, in particular, among them: the accelerated nature of transformations, social consensus and solidarity.

3. The special features of the East Asian model of modernization are revealed:

- the special role of governments in planning modernization strategies;

- competent bureaucracy with a minimum degree of corruption;

- authoritarian methods of transformation.

The political practices of the East Asian states indicate the prevalence of a greater number of non-Western democracies in the region, those countries that have managed to synthesize democratic principles and constitutional liberalism with the peculiarities of their political culture, including the specifics of the confessional organization of society and, in some countries, the state. They set the general vector of regional development. Regimes with a different vector of political development rigidly authoritarian or military rule - are in the minority.

It is among the East Asian countries that there are those that show the most impressive regional (and world) economic growth (Japan, South Korea, Taiwan, Singapore), and this growth is carried out not on the basis of a mobilization model of violent development, but on the basis of modernization as a special, synthetic paths, not Western and not mobilization type. These countries were able to overcome the external challenges of the West and caught up with the Western polities in virtually all parameters, regardless of their geographic or demographic size, resource availability, etc., while changing the economic and political map of the world.

\section{References}

Bell D.A. (2006) Beyond Liberal Democracy. Political Thinking for an East Asian Context. Princeton: Princeton University Press. P. 153-179.

Bunce, Valerie J., and Sharon L. Wolchik. (2010) Defeating Dictators: Electoral Change and Stability in Competitive Authoritarian Regimes. World Politics. 62: 43-86.

Glasius, Marlies. (2018) What Authoritarianism is ... and is not: A Practice Perspective. International Affairs. 94: 515-533.

He, Baogang, and Hendrik Wagenaar. (2018) Authoritarian Deliberation Revisited. Japanese Journal of Political Science. 19: 622-629.

Lührmann, Anna, and Staffan I. Lindberg. (2019) A Third Wave of Autocratization is Here: What is New About It? Democratization. 26: 1095-1113.

Martinelli A. (2005) Global Modernization. London: Sage Publications. P. 44-46.

Morgenbesser, Lee. (2020) The Rise of Sophisticated Authoritarianism in Southeast Asia. New York: Cambridge University Press.

Organski A.F.K. (1956) The Stages of Political Development. New York: Free Press. P. 35-67.

Svolik, Milan W. (2012) The Politics of Authoritarian Rule. Cambridge: Cambridge University Press. 
Sztompka P. (1992) Dilemmas of the Great Transition / Harvard Centre for European Studies Working Paper. No 19. Cambridge, Mass. P. 21-23.

Waldner, David, and Ellen Lust. (2018) Unwelcome Change: Coming to Terms with Democratic Backsliding. Annual Review of Political Science. 21: 93-113.

Waldner, David, and Ellen Lust. (2018) Unwelcome Change: Coming to Terms with Democratic Backsliding. Annual Review of Political Science. 21: 93-113.

Yang L. (1994) Cross-Talk and Culture in Sino-American Communication. Cambridge: Cambridge University Press.

\section{Summary}

Teslenko S. S. Political practices of transformation of East and Southeast Asia countries. - Article.

The article considers models of political transformation in East Asian countries.

The analysis of political practices of transformation of the countries of East and South-East Asia is carried out in the study. The research contains the factors that influenced the successful implementation of modernization projects in the states of the region. The specific features of the political transformations of the states of the region associated with the formation of non-Western democracies on the basis of "development authoritarianisms" are revealed.

Carrying out large-scale transformations is connected with the need to establish sovereignty in the postcolonial period and ensure national security in the current geopolitical conditions. The success of the East Asian model of transformation is also associated with the preservation of elements of traditional regulation, a unique synthesis of traditions and innovations based on a special, synthetic way, non-Western and nonmobilization type.

Governments and national leaders play a special role in the political practices of non-Western modernization, ensuring the planning of modernization strategies. A separate role in the transformation belongs to the competent bureaucracy with a minimum degree of corruption. And the transformations were carried out by authoritarian methods.

Non-Western modernization is of interest both from a theoretical and empirical point of view, especially given the effect of the non-Western approach to transformation, embodied in the so-called Asian economic miracle and contributing to national consolidation in Southeast and East Asia.

For developing countries, it is important to choose the ways of their socio-political and economic development, especially in the context of globalization. The study of the experience of the countries of Southeast and East Asia allows us to identify the main directions of their development that have transformed societies, and to determine an acceptable development strategy for the state.

Back in the 1990s, concepts were put forward according to which the 21st century would be the era of domination of the Asia-Pacific civilization, which replaces the Euro-Atlantic one. The modernization of the countries of Southeast Asia is becoming a factor in reformatting the established world order, creating a new balance of power in the international arena and new centres of influence in political and economic relations.

Key words: political transformation, Southeast Asia, political process, non-Western democracies, authoritarianism, political culture.

\section{Анотація}

Тесленко С. С. Політичні практики трансформації країн Східної та Південно-Східної Азії. Стаття.

У статті розглядаються моделі політичної трансформації в східноазійських державах.

Здійснено аналіз політичних практик трансформації країн Східної та Південно-Східної Азії; досліджено чинники, що вплинули на успішну реалізацію модернізаційних проєктів у державах регіону; виявлено специфічні риси політичних трансформацій держав регіону, пов'язані з формуванням незахідних демократій на основі «авторитаризмів розвитку».

Проведення широкомасштабних перетворень пов'язане з необхідністю утвердження суверенітету в постколоніальний період і забезпечення національної безпеки у сучасних геополітичних умовах. Успіх східноазійської моделі трансформації зв'язується також зі збереженням елементів традиційної регуляції, унікальним синтезом традицій і новацій на основі особливого, синтетичного шляху, незахідного і немобілізаціонного типу.

В політичних практиках незахідної модернізації особливу роль відіграють уряди і національні лідери, що забезпечують планування стратегії модернізації. Окрема роль у перетвореннях належить компетентній бюрократії з мінімальним ступенем корупції. А перетворення здійснені авторитарними методами. 
Незахідна модернізація становить інтерес як з теоретичної, так і з емпіричної точок зору, особливо з огляду на ефект від незахідного підходу до трансформації, що втілився у так званому азійському економічному диві та сприяв національній консолідації у країнах Південно-Східної та Східної Азії.

Для країн, що розвиваються, важливим є вибір шляхів їх соціально-політичного і економічного розвитку, особливо в умовах світової глобалізації. Вивчення досвіду країн Південно-Східної та Східної Азії дозволяє виявити основні напрями їх розвитку, що трансформували суспільства, і визначити прийнятну для держави стратегію розвитку.

Ще у 1990-х роках були висунуті концепції, згідно з якими XXI століття стане епохою домінування Азійсько-тихоокеанської цивілізації, яка йде на зміну Євроатлантичній. Модернізація країн Південно-Східної Азії стає фактором переформатування усталеного світоустрою, створюючи новий баланс сил на міжнародній арені і нові центри впливу в політичному та економічному відношеннях.

Ключові слова: політична трансформація, Південно-Східна Азія, політичний процес, незахідні демократії, авторитаризм, політична культура. 